\title{
Vaihtohappamuutta lisäävän lannoitteen vaikutus maahan, perunan satoon ja sadon laatuun
}

\author{
Kristian Forsman ${ }^{1)}$ ja Väinö Mäntylahti ${ }^{2)}$ \\ ${ }^{1)}$ MTT Pohjois-Pohjanmaan tutkimusasema, 92400 Ruukki, kristian.forsman@mtt.fi \\ ${ }^{2)}$ Kemira GrowHow Oyj, ERC, PL 2, 02271Espoo, vaino.mantylahti@kemira-growhow.com
}

\section{Tiivistelmä}

Maan vaihtohappamuudella tarkoitetaan liukoisten happamien kationien määrää maassa. Se on japanilaisten tutkimustulosten mukaan erinomainen muuttuja kuvaamaan perunaruven ilmenemistä sadossa. Vaihtohappamuuden ja sadon rupisuuden yhteys on ollut selvempi kuin maan $\mathrm{pH}: \mathrm{n}$ ja sadon rupisuuden yhteys, jota on vanhastaan pidetty yhtenä tärkeimmistä maan rupiriskiä ennustavista tekijöistä.

Maan vaihtohappamuuden manipuloimiseksi Kemira GrowHow Oyj valmisti koelannoitteen ammoniumsulfaatista, ferrosulfaatista, mangaanisulfaatista ja kalsiumsulfaatista. Tuotteen $\mathrm{pH}$ on 3,6 ja sen ravinnepitoisuudet ovat (\%): N 8.9, Ca 7.1, Fe 3.8, Mn 4.2 ja S 21.3. Hapanta lannoitetta lisättiin asteittain 20 kilon typpiportailla. Typpimäärät tasattiin Suomensalpietarilla 80 kiloon hehtaarille. Hapan lannoite annettiin sijoittamalla ja Suomensalpietari hajalevitettiin. Kenttäkoe perustettiin vähämultaiselle HHtmaalle Liminkaan. Kentän viljavuusluvut olivat pH 7.0, Ca 1680, P 28, K 145, Mg 120, S 128, Cu 2.9, Mn 16 ja Zn 1.0. Lajikkeena oli Van Gogh.

Maanäytteet otettiin kentältä ruuduittain kolmeen otteeseen, keväällä, kesällä ja syksyllä. Maanäytteistä mitattiin normaalien viljavuuslukujen lisäksi erilaisia $\mathrm{pH}$-arvoja $\left(\mathrm{pH}_{(\mathrm{H} 2 \mathrm{O})}, 1 \mathrm{M} \mathrm{pH}_{(\mathrm{KCl})} \mathrm{ja} 0,01 \mathrm{M}\right.$ $\left.\mathrm{pH}_{\text {(CaCl2) }}(1: 2,5)\right)$. Vaihtohappamuus määritettiin titraamalla KCl-suodos 0,1 M NaOH:Ila ja määrittämällä suodoksen Al- ja Mn-pitoisuudet ICP:llä. Vaihtohappamuus lasketaan summana $(\mathrm{H}+\mathrm{Al}) \mathrm{mmol} / \mathrm{kg}$. Perunakasvustosta ja sadosta havainnoitiin tyypilliset kehitys-, määrä- ja laatumuuttujat. Rupi määritettiin rupiluokittain.

Kesänäytteenotossa maan pH oli alhaisin pelkkää Suomensalpietaria lannoitukseensa saaneella koejäsenellä. Vaikutus on ilmeisesti seurausta ennen kaikkea salpietarin hajalevityksestä, ts. lannoitustavasta, mutta happaman koelannoitteen vaikutuksen vähäisyys lienee myös seurausta alkukasvukauden kuivuudesta. Syksyn maa-analyyseissä hapan lannoite näyttäytyi aktiivisena. Sen ansiosta maan pH on laskenut. Vaikutus oli vesi-pH:ssa luokkaa 0,1 pH-yksikköä jokaista typpiporrasta kohti välillä 0-60 kg $\mathrm{N} / \mathrm{ha}$ ja suola-pH:ssa jonkin verran pienempi (-0,06 pH-yksikköä). Viimeisessä happaman lannoitteen typpiportaassa eroa ei edelliseen portaaseen enää ollut. Hapan lannoitus heijastui maan rikki- ja mangaanilukuihin sekä johtolukuun. Näissä muutos on havaittavissa vielä viimeisessäkin typpiportaassa.

pH-vaikutus ei ilmeisesti kuitenkaan ollut tarpeeksi voimakas vaikuttamaan vallitsevan rupibakteerikannan kasvuoloihin maassa, sillä rupea vähentävää vaikutusta ei happamalla lannoitteella ollut. Päinvastoin, ruvella ja pH:lla oli tässä kokeessa negatiivinen korrelaatio. Varsinaisia vaihtohappamuusanalyysejä ei pystytty hyödyntämään, sillä happamien kationien aktiivisuus maassa oli niin pieni, että niiden pitoisuus jäi käytetyillä analyyseillä alle määritysrajan. Mikään mitattu muuttuja ei kokeessa pystynyt selittämään sadon toteutunutta rupivioitusta.

Sadon tuottajana koelannoite toimi moitteettomasti, ja sadon määrä nousi lannoitusta koelannoitteella lisättäessä. Sadon mangaanipitoisuus nousi myös. Kokeita tultaneen jatkamaan vaihtohappamuuden vaikutusten selvittämiseksi tulevina vuosina niin kentällä kuin kasvihuoneessakin.

\section{Asiasanat:}

vaihtohappamuus, happamuus, vaihtuva alumiini, mangaani, peruna, perunarupi, lannoitus 


\section{Johdanto}

Maan pH:n pitäminen mahdollisimman alhaisella tasolla on perinteisesti ollut tärkeällä sijalla perunanviljelijöiden ruventorjuntastrategiassa. Perunaruven (Streptomyces sp.) muodostuminen mailla, joiden $\mathrm{pH}$ on alle 5,3 - 5,5, on käytännön havaintojenkin perusteella ollut vähäistä tai ainakin vähäisempää kuin korkeammissa pH-luokissa (Pietilä 1993). Siltikin ruven määrä sadossa voi vaihdella samasta pH-alueesta huolimatta eri viljelijöiden pelloilla tai jopa yksittäisen lohkon sisällä. Vaikuttavia tekijöitä erilaiseen ruven ilmenemiseen voidaan etsiä biologisista, fysikaalisista ja kemiallisista muuttujista. Rupibakteerikantojen ja -lajien on todettu sopeutuneen erilaisiin maaoloihin, mm. happamammille maille, joten alhainen, tai pellossa valitseva $\mathrm{pH}$ ei välttämättä enää vaikuta rupea ehkäisevästi (Valkonen ym. 1999, Lehtonen ym. 2003). Fysikaalisista tekijöistä ruven menestymiseen vaikuttaa maan lämpötila- ja kosteusolosuhteet (Pietilä 1993). Kemiallisiin tekijöihin voidaan pH:n lisäksi nimetä, joskin huomattavasti pienemmällä painoarvolla, ravinteita esim. mangaani, kupari, rauta ja rikki (Keinath \& Loria 1989). Toteutettu viljelytekniikka, kuten lajikevalinta, sadetus, lannoitus tai viljelykierto, vaikuttaa kokonaisvaltaisesti kaikkien em. tekijöiden kautta ruven esiintymiseen.

Japanilaisten tutkimustulosten mukaan maan vaihtohappamuudesta voidaan löytää selitys eri maiden rupialttiuteen (Saigusa et al. 1980, Mizuno \& Yoshida 1993, Shiga \& Suzuki 2004). Kokeissa on maan vaihtohappamuutta onnistuneesti manipuloitu erilaisilla lisäaineilla/maanparannusaineilla (rautasulfaatilla ja alumiinisulfaatilla) ja sadon rupisuus on samalla selkeästi vähentynyt (Mizuno \& Yoshida 1993, Shiga \& Suzuki 2004, Tanaka 2004). Ruven esiintymisen ja maan vaihtohappamuuden välillä on ollut mm. huomattavasti parempi korrelaatio kuin mitä ruvella ja $\mathrm{pH}$ :lla olisi ollut.

Maan vaihtohappamuudella tarkoitetaan sellaisten happamien kationien pitoisuutta maassa, jotka voivat vallitsevassa pH-tilassa toimia happoina. Näistä suurin merkitys käytännössä on maan vaihtuvalla alumiinilla $\left(\mathrm{Al}^{3+}\right)$. Muita happamia kationeja ovat $\mathrm{Mn}^{2+}, \mathrm{Fe}^{2+}, \mathrm{Fe}^{3+} \mathrm{ja} \mathrm{Si}^{4+}$. Maan vaihtohappamuus lisääntyy maan $\mathrm{pH}: n$ laskiessa, joten siinäkin mielessä se on $\mathrm{pH}$ :lle rinnasteinen menetelmä. Alhaisessa $\mathrm{pH}$ :ssa (pH 5,0 - 5,5) maan vaihtohappamuus alkaa nopeasti kasvaa (Saigusa et al. 1980, Hartikainen 1992, Mizuno \& Yoshida 1993, Mäntylahti 2005).

\section{Aineisto ja menetelmät}

Kemira GrowHow Oyj valmisti maan vaihtohappamuuden nostamiseksi happaman lannoitteen, joka koostui ammoniumsulfaatista, ferrosulfaatista, mangaanisulfaatista ja kalsiumsulfaatista. Tuotteen pH on 3,6 ja sen ravinnepitoisuudet ovat (\%): N 8.9, Ca 7.1, Fe 3.8, Mn 4.2 ja S 21.3. Hapanta lannoitetta lisättiin asteittain typpiportaan $20 \mathrm{~kg} / \mathrm{ha}$ mukaisesti. Happaman lannoitteen käyttömäärät olivat 0, 225, 450, 675 ja 900 kg/ha. Typpimäärät tasattiin Suomensalpietarilla (NPK 26-0-1) 80 kiloon hehtaarille. Suomensalpietarin vastaavat käyttömäärät olivat siten 308, 231, 154, 77 ja 0 kg/ha. Hapan lannoite annettiin sijoituslannoituksena, kun taas Suomensalpietari hajalevitettiin käsin ruutujen pinnalle ensimmäisen istutusmuokkauskerran jälkeen. Lannoitustavan vaikutuksen selvittämiseksi kokeeseen lisättiin koejäsen, joka sai happaman lannoitteen (450 kg/ha) hajalevityksenä ja Suomensalpietarin (154 kg/ha) sijoittamalla. Peruslannoitus hoidettiin antamalla Puutarhan PK (NPK 0-5-20) -lannoitetta koko koealalle 800 kg/ha.

Kenttäkoe perustettiin vähämultaiselle (hehkutushäviönä mitattu humuspitoisuus keskimäärin 2,96 \%) HHt-maalle Liminkaan. Kentän ravinneluvut olivat seuraavat (Viljavuuspalvelu): Ca 1680, P 28, K 145, Mg 120, S 128, Cu 2.9, Mn 16 ja Zn 1.0. Kenttä on ollut alueelle tyypillisessä ruokaperunakierrossa, joskin erityisesti sen $\mathrm{pH}$ on tavanomaista perunapeltoa korkeampi $\left(\mathrm{pH}_{(\mathrm{H} 20)} 6,8-7,0\right.$, Taulukot 1 ja 2). Koemalli oli lohkottain satunnaistettu koe neljällä toistolla. Lajikkeena käytettiin Van Goghia. Kenttäkoe istutettiin 28.5. ja nostettiin 30.8.

Maanäytteet otettiin kentältä ruuduittain kolmeen otteeseen. Ensimmäinen näytteenottokerta oli keväällä ennen istutusta ja lannoitusta alkutilanteen havainnollistamiseksi, toinen näytteenottokerta sijoittui perunalla mukulanmuodostuksen alkuun, jolloin mukulan alku on herkimmillään rupibakteerin iskeä ja kolmas näytteenottokerta noston jälkeen lopputilanteen määrittämiseksi. Joka kerta otettiin rinnakkaisnäytteet, joista toiset lähetettiin Viljavuuspalvelu Oy:öön ja toiset Kemiran Espoon tutkimuskeskukseen. Viljavuuspalvelu tuotti näytteistä viljavuusanalyysin hivenineen sekä pH:n kaliumkloridi-uutoksesta (1 M, 1:2,5) maan suolaväkevyydestä riippumattoman happamuuden määrittämiseksi.

Kemiran Espoon tutkimuskeskus määritti näytteistä erilaisia $\mathrm{pH}$-arvoja sekä vastasi varsinaisista vaihtohappamuusanalyyseistä. Espoossa näytteiden vesi-pH sekä $1 \mathrm{M} \mathrm{pH}_{(\mathrm{KCl})}$ ja $0,01 \mathrm{M} \mathrm{pH}_{(\mathrm{CaCl} 2)}(1: 2,5)$ mitattiin. Vesi- ja kaliumkloridisuodoksesta mitattiin lisäksi uuttuva orgaaninen hiili. Vaihtohappamuus 
määritettiin titraamalla KCl-suodos 0,1 M NaOH:lla (Saigusa et al. 1980, Mizuno \& Yoshida 1993, Hartikainen, suullinen tiedonanto 2005), jonka perusteella $\mathrm{H}^{+}$-konsentraatio laskettiin. Suodoksen $\mathrm{Al}$ - ja $\mathrm{Mn}-$ pitoisuudet määritettiin ICP:llä, vaihtohappamuus laskettiin summana $(\mathrm{H}+\mathrm{Al}) \mathrm{mmol} / \mathrm{kg}$.

MTT Pohjois-Pohjanmaan tutkimusasema vastasi kokeen hoidosta. Ruuduilta havainnoitiin taimettuminen, kehitysaste neljä kertaa kasvukauden aikana sekä kasvustotaudit. Sadon määrä punnittiin kokoluokittain ja sadon ulkoinen laatu ja tärkkelys määritettiin standardimenetelmin. Rupi määritettiin siten, että jokainen yli 30-millinen satomukula luokiteltiin ruven ankaruuden suhteen seuraaviin luokkiin: ei havaittavaa rupea, ruven osuus mukulan pinnasta $0-1 \%, 1-10 \%$ rupea, $10-25 \%$ rupea tai rupisuus $>25 \%$ mukulan pinnasta. Rupi-indeksi on em. luokkien painotettu keskiarvo. Myös sadon keittolaatu määritettiin. Sadon ravinnepitoisuudet ( $\mathrm{P}, \mathrm{K}, \mathrm{Ca}, \mathrm{Mg}, \mathrm{S}, \mathrm{Na}, \mathrm{B}, \mathrm{Cu}, \mathrm{Mn}, \mathrm{Zn}$ ja Fe) määritettiin Viljavuuspalvelussa.

Kasvukauden sää keskimäärin hyvin lämmin. Tehoisaa lämpösummaa kertyi Ruukissa lähes 250 astetta pitkäaikaiskeskiarvoa enemmän. Kesäkuu oli Pohjois-Pohjanmaalla poikkeuksellisen kuiva, ja sateetonta kautta jatkui heinäkuun puoleenväliin. Heinä- ja elokuun sadesumma ylsi normaaliksi.

\section{Tulokset ja tulosten tarkastelu Vaikutus maahan}

Kenttä oli suhteellisen tasalaatuinen, joskin koejäsenessä Hapan40Nhajalle olivat ravinnepitoisuudet jonkin verran muita korkeampia. Mangaanissa ero oli tilastollisesti merkitsevä koejäseniin Hapan0N ja 20N ja $\mathrm{pH}_{(\mathrm{KCl})}$ :ssa Hapan0N:ään $(\mathrm{p}<0,05)$.

Mitään perustavanlaatuisia muutoksia ei hapan lannoitus saanut aikaan vielä heinäkuun alkupuolella tehtyyn toiseen maanäytteiden ottokertaan mennessä. Saattaa olla, että tämä on kuivan alkukasvukauden tulosta. Ravinnepitoisuudet olivat kyllä kalsiumia lukuun ottamatta kauttaaltaan koko koealalla nousseet, mutta koejäsenet eivät juuri eronneet toisistaan. Koejäsen 40Nhaja erosi korkeamman johto- ja mangaanilukunsa kanssa osasta muita koejäseniä, mutta tämän koejäsenen alkupitoisuudet olivat jo jossain määrin muita korkeampia.

pH-luvuissa oli kuitenkin toisella näytteenottokerralla tapahtunut koejäsenten erilaisista käsittelyistä johtuvia liikahduksia (Taulukko 1). Happamat lannoitteet eivät kuitenkaan näytä tuolloinkaan olleen aktiivisessa roolissa, vaan maan sekä vesi- että suola-pH:t olivat happamilla lannoiteruuduilla nousussa. Tämä johtuu todennäköisesti siitä, että kasvuston aikaan maanäytteet otetaan penkistä, jolloin hajalevitetyt lannoitteet vaikuttavat niissä suhteessa enemmän. Sijoituslannoituksena annettava lannoitus kohdistuu puolestaan enemmän penkin alapuolelle ja sivuun. Kokeen luonteeseen penkistä tapahtuva näytteenotto sopii hyvin, sillä rupialtistuskin tapahtuu mukulapesässä. Havaittu pH:n nousu happaman lannoitteen käyttömäärän lisääntyessä kertoneen kuitenkin enemmän hajalevitetyn lannoitteen (=Suomensalpietari paitsi koejäsenessä 40Nhaja ammoniumsulfaatti) sisältämän ammoniumtypen nitrifikaation tuottamasta $\mathrm{pH}: n$ laskusta penkin alueella. Eri lannoitustapoja, eli Hapan 40N ja Hapan 40Nhaja -koejäseniä vertailtaessa, ei eroja löydy, mikä kertoo, ettei lannoitusaineiden välisiä eroja tässä vaiheessa kasvukautta ole.

Taulukko 1. Maan pH:n muutokset kasvukauden aikana $\left(\mathrm{pH}_{(\mathrm{H} 20)} \mathrm{ja} \mathrm{pH}_{(\mathrm{CaCl} 2)}\right.$ Kemira, Espoo) koejäsenittäin*

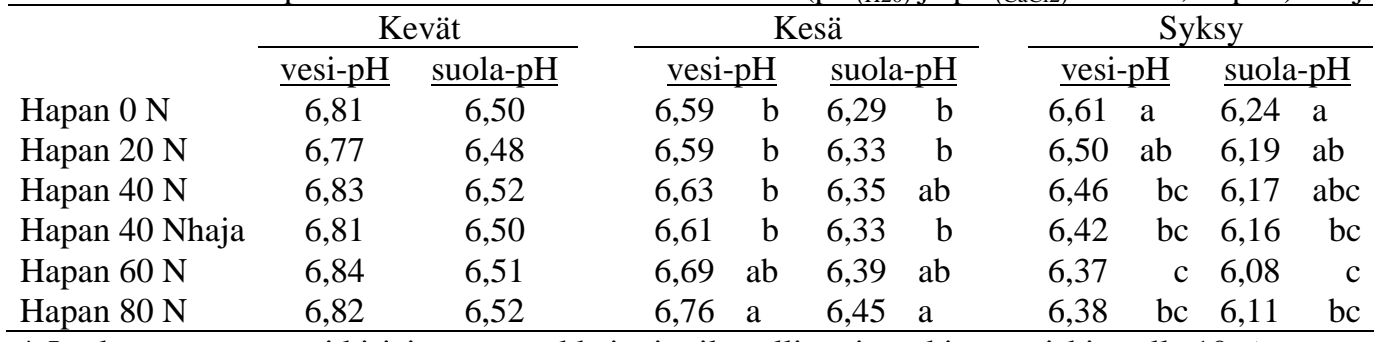

* Jos luvun perässä eri kirjain, ero sarakkeittain tilastollisesti merkitsevä riskitasolla 10 \%

Vasta syksyisessä noston jälkeen otetussa maanäytteessä nähdään koelannoitteen maata happamoittava vaikutus (Taulukot 1 ja 2). Trendi on selvä jokaisessa $\mathrm{pH}$-analyysissä, niin vesiuutossa kuin happamilla uuttonesteilläkin suoritetuissa analyyseissä. Kasvukauden alusta vesi-pH on kummassakin analyysissä tippunut noin $0,1 \mathrm{pH}$-yksikköä jokaista 20 typpikiloa kohti välillä $0-60 \mathrm{~N}$ verrattuna kontrollissa tapahtuneeseen muutokseen. Suola-pH:ssa tiputus on jonkin verran pienempi (-0,06 pH-yksikköä). Viimeisessä typpiportaassa (60:stä 80 kiloon) ei ole nähtävissä pH-muutoksia. 
Koelannoitteen vaikutus maan ravinnepitoisuuksiin tulee ilmi myös viimeisessä näytteenotossa. Erityisesti maan rikki- ja mangaaniluvut ovat lannoituksen yhteydessä nousseet, samoin kuin johtoluku (Taulukko 2). Näissä muutos on havaittavissa vielä viimeisessäkin typpiportaassa.

Taulukko 2. Viljavuusluvut loppunäytteessä sekä kasvukauden aikana tapahtunut muutos (Viljavuuspalvelu)

\begin{tabular}{|c|c|c|c|c|c|c|c|c|c|c|c|c|c|c|c|}
\hline \multirow[b]{3}{*}{$0 \mathrm{~N}$} & \multicolumn{4}{|c|}{ vesi-pH } & \multicolumn{4}{|c|}{ Johtoluku } & \multicolumn{4}{|c|}{ Rikki } & \multicolumn{3}{|c|}{ Mangaani } \\
\hline & \multicolumn{2}{|c|}{ loppu } & \multicolumn{2}{|c|}{ muutos } & \multicolumn{2}{|c|}{ loppu } & \multicolumn{2}{|c|}{ muutos } & \multicolumn{2}{|c|}{$\underline{\text { loppu }}$} & \multicolumn{2}{|c|}{ muutos } & \multicolumn{2}{|c|}{ loppu } & $\underline{\text { muutos }}$ \\
\hline & $6, \overline{65}$ & $\bar{a}$ & $-0,35$ & $\bar{a}$ & 5,0 & b & 1,5 & $\bar{b}$ & 242 & C & 133 & d & 18 & C & 2,5 \\
\hline $20 \mathrm{~N}$ & 6,48 & bc & $-0,49$ & $a b$ & 6,3 & $a b$ & 2,3 & $a b$ & 350 & $\mathrm{~b}$ & 209 & bcd & 20 & bc & 4,5 \\
\hline $40 \mathrm{~N}$ & 6,50 & b & $-0,54$ & b & 6,4 & $a b$ & 2,9 & $\mathrm{a}$ & 380 & $a b$ & 256 & $a b c$ & 24 & $a b$ & $8,2 \mathrm{ab}$ \\
\hline 40Nhaja & 6,49 & bc & $-0,56$ & b & 6,3 & $a b$ & 2,1 & $a b$ & 333 & $\mathrm{~b}$ & 176 & $\mathrm{~cd}$ & 22 & bc & 5,0 \\
\hline $60 \mathrm{~N}$ & 6,38 & C & $-0,65$ & b & 6,2 & $a b$ & 3,1 & $\mathrm{a}$ & 365 & $a b$ & 268 & $a b$ & 28 & $\mathrm{a}$ & 12,3 a \\
\hline $80 \mathrm{~N}$ & 6,38 & $\mathrm{C}$ & $-0,66$ & $\mathrm{~b}$ & 7,3 & $\mathrm{a}$ & 3,4 & $\mathrm{a}$ & 448 & $\mathrm{a}$ & 311 & $\mathrm{a}$ & 29 & $\mathrm{a}$ & 12,6 a \\
\hline
\end{tabular}

* Jos luvun perässä eri kirjain, ero sarakkeittain tilastollisesti merkitsevä riskitasolla $10 \%$

Varsinaisia vaihtohappamuusanalyysejä ei valitettavasti voitu hyödyntää. Maa oli tyypiltään ja/tai pHarvoltaan sellainen, että sen sisältämät liukoisten happamien kationien aktiivisuudet olivat hyvin pieniä. Käytetyillä menetelmillä ei niitä pystytty analysoimaan, vaan pitoisuudet olivat alle määritysrajan $(\mathrm{Al}<2,5$ $\mathrm{mg} / \mathrm{kg}, \mathrm{Mn}<1,25 \mathrm{mg} / \mathrm{kg}$ ).

\section{Vaikutus perunaan}

Taimettuminen parani koelannoitteen käyttömäärää lisättäessä (Taulukko 3). Erot taimettumisessa heijastuivat kasvuston kehitykseen ja lopulta myös satoon. Sadon määrä lisääntyi hapanta lannoitetta käytettäessä aina 60 kg N/ha asti, ja kontrollin ero muihin paitsi Hapan20N-koejäseneen oli tilastollisesti suuntaaantavasti merkitsevä ( $<<0,10$, Taulukko 3). Trendi on vielä selkeämpi tarkasteltaessa tärkkelyssatoa.

Taulukko 3. Kokonais- ja tärkkelyssato, taimettuminen sekä sadon mangaanipitoisuus koejäsenittäin

\begin{tabular}{|c|c|c|c|c|c|c|c|}
\hline & \multicolumn{2}{|c|}{ Kokonaissato } & \multicolumn{2}{|c|}{ Tärkkelyssato } & \multirow{2}{*}{\multicolumn{2}{|c|}{ Taimettuminen }} & \multirow{2}{*}{$\frac{\text { Mukulan Mn-pit. }}{\mathrm{mg} / \mathrm{kg} \mathrm{ka}}$} \\
\hline & t/ha & suhdeluku & $\mathrm{kg} / \mathrm{ha}$ & suhdeluku & & & \\
\hline Hapan $0 \mathrm{~N}$ & 34,5 & $100 \mathrm{~b}$ & 5660 & 100 & 24,25 & $\mathrm{a}$ & 5,5 \\
\hline Hapan $20 \mathrm{~N}$ & 37,0 & $107 \mathrm{ab}$ & 5900 & 104 & 24,00 & $\mathrm{ab}$ & 6,5 \\
\hline Hapan $40 \mathrm{~N}$ & 37,8 & $110 \mathrm{a}$ & 6030 & 106 & 23,00 & bc & 8,0 \\
\hline Hapan 40 Nhaja & 37,4 & $108 \mathrm{ab}$ & 6020 & 106 & 22,00 & C & 6,0 \\
\hline Hapan $60 \mathrm{~N}$ & 39,8 & 115 a & 6610 & $117 \mathrm{a}$ & 22,75 & C & 7,5 \\
\hline Hapan $80 \mathrm{~N}$ & 38,7 & $112 \mathrm{a}$ & 6220 & 110 & 23,00 & bc & 13,3 a \\
\hline
\end{tabular}

* Jos luvun perässä eri kirjain, ero sarakkeittain tilastollisesti merkitsevä riskitasolla 5 \%

Sadon laatutekijöistä tärkkelyspitoisuudessa ei ollut koejäsenien välillä eroa, kuten ei myöskään keittolaadussa. Sadon ulkoisen laadun tarkastelussa huomattiin, että kontrollissa oli epämuotoisia mukuloita 5,9 \% sadon määrästä, kun se muilla oli $0,6-2,5 \%$. Ero muihin on tilastollisesti merkitsevä $(p<0,05)$. Sadon epämuotoisuus on yleensä perunaseitin (Rhizoctonia solani) aikaansaannosta. Kasvustossa seittiä havaittiin kontrollissa keskimäärin muita enemmän, mutta ero muihin oli varsin pieni. Laatutulosten perusteella saattaa kuitenkin olla niin, että kontrollissa seitin merkitys oli muita suurempi ja se saattaa osaltaan selittää kontrollin keskimääräistä heikomman satotuloksen.

Sadon ravinnepitoisuuksiin koelannoitteella ei ollut vaikutusta mangaania lukuun ottamatta. $\mathrm{Mu}-$ kulan mangaanipitoisuus nousi lievästi hapanta lannoitetta lisättäessä, kunnes suurimmalla lannoitemäärällä ero oli selkeä ( $<<0,01$, Taulukko 3).

Hapan lannoite ei kyennyt vähentämään ruven määrää sadossa. Itse asiassa kävi päinvastoin, sillä kontrollissa oli keskimäärin vähemmän rupea kuin muissa koejäsenissä. Rupi-indeksinä laskettuna ero kontrollin ja muiden välillä oli noin $20 \%$. Erityisesti täysin ruvettoman ja vähärupisen perunan osuus oli kontrollissa suurempi kuin muilla (Kuva 1). Erot koejäsenten välillä eri luokissa tai rupi-indeksinä eivät pääsääntöisesti ole tilastollisesti merkitseviä, mutta laskettaessa extra-luokan perunan osuutta (rupea alle $10 \%$ perunan pinnasta) kokonaissadosta eroaa kontrolli Hapan 40N ja Hapan $60 \mathrm{~N}$-koejäsenistä $(\mathrm{p}<0,05)$. 


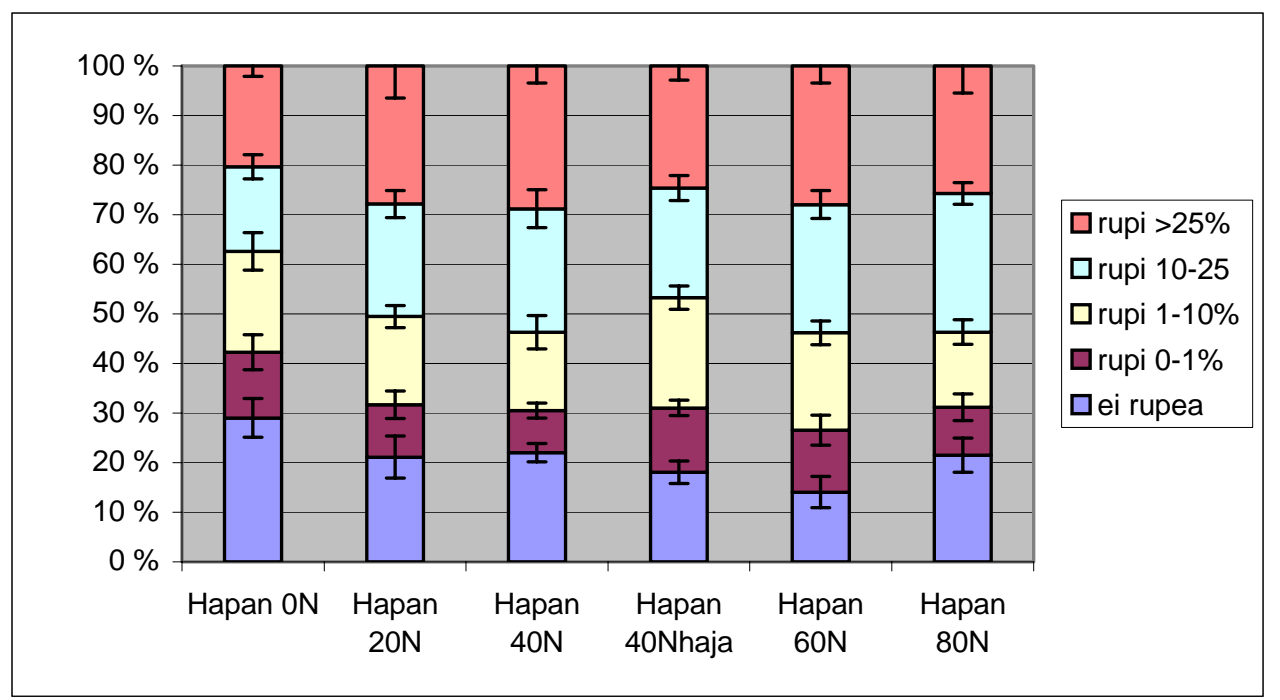

Kuva 1. Ruven määrä rupiluokittain eri käsittelyissä. Virhepalkit kuvaavat keskihajontaa.

\section{Johtopäätökset}

Happaman lannoitteen käyttämisellä pyrittiin vaikuttamaan maan vaihtohappamuuteen ja vähentämään perunaruven esiintymistä sadossa. Tässä ei kuitenkaan onnistuttu, sillä ruven määrä ei koelannoitteella laskenut. Varsinaisten vaihtohappamuusanalyysien käyttöä rajoitti niiden lukuarvojen jääminen alle määritysrajan, sillä kenttäkoe perustettiin ilmeisesti pH:Itaan liian korkealle maalle. Maan happamuutta pystyttiin lannoituksella laskemaan, joten ilmeisesti vaihtohappamuuskin reagoi ainakin hieman. Maan $\mathrm{pH}-$ vaikutus oli kuitenkin melko pieni, maksimissaan $0,2-0,3 \mathrm{pH}$-yksikköä, joten mahdollisesti vaikutus oli liian pieni, jotta sillä olisi ollut merkitystä vallitsevalle rupibakteerikannalle. Japanilaisissa kokeissa käsittelyiden $\mathrm{pH}_{(\mathrm{H} 2 \mathrm{O})}$-tavoitetaso oli 5,0 ja siihen pääsemiseksi maanparannusainetta (yleensä ferrosulfaattia) käytettiin huomattavan suuria määriä, 2 - 7 t/ha (Mizuno \& Yoshida 1993, Shiga \& Suzuki 2004, Tanaka 2004).

Ruven esiintymistä kokeessa on vaikea selittää. Mikään mitatuista muuttujista ei selitä tai ennusta lähellekään hyvin toteutunutta sadon rupisuutta. pH-tekijä on yksi tärkeimmistä ruven esiintymiseen vaikuttavista tekijöistä, mutta tässä kokeessa sen korrelaatio oli negatiivinen, kun yleensä sanotaan, että pH:n noustessa rupiriski kasvaa. Rupikorrelaatio oli negatiivinen myös toisessa maanäytteenotossa, vaikka keskimäärin silloin happamin koejäsen (kontrolli) osoittautui myöhemmin ruvettomimmaksi. Maasta mitatuista tunnusluvuista kaikkein parhaan selitysasteen antoi kuitenkin edelleen vesi-pH (viimeisessä näytteenotossa $\mathrm{r}^{2} \sim 30 \%$ ). Kesällä tehty näytteenotto oli kaikkein huonoin ennustamaan lopullista rupitulosta, ensimmäisessä näytteenotossa parhaan selitysasteen antoi maan P-luku. Ilmeisestikin muut kuin kemialliset tekijät aikaansaivat kyseisissä koeoloissa toteutuneen rupivioituksen.

Sadontuottajana hapan lannoite oli hyvä. Mitään polttovioituksia tai vastaavaa ei kokeen aikana havainnoitu, mistä oli viiteitä mm. Forsman ym.:n (2003) kokeessa ureafosfaatilla. Sato nousi hapanta lannoitusta lisättäessä. Tämä kertonee ennen kaikkea sijoituslannoituksen tärkeydestä, sillä sijoitetun typen määrä nousi hapanta lannoitetta käytettäessä hajalevitetyn typen kustannuksella. Hajalevitetyn typen hitaampi vaikutus tuli ilmi jo taimettumisvaiheessa. Sato nousi melko suoraviivaisesti 60 sijoitettuun ja 20 hajalevitettyyn typpikiloon hehtaarille asti. Ruokaperunan peruslannoitustaso typellä on $60 \mathrm{~kg} / \mathrm{ha}$, eikä sitä tämänkään kokeen perusteella ole suuresti tarvetta ylittää. Lannoitelajilla ei välttämättä ole niin suurta merkitystä, ainakaan kokeeseen sisällytetyt lannoitustapavaihtoehdot eivät eronneet toisistaan. Toisaalta tämän kokeen rinnalla vedettyjen kasvihuonekokeiden perusteella näyttävät alustavat koetulokset samanlaisilta siten, että hapan lannoite lisäsi sadontuottoa (julkaisematon tieto). Täten ammoniumsulfaatilla tai jollain muulla happaman lannoitteen tekijällä saattaa olla perunan sadonmuodostusta parantavia tekijöitä Suomensalpietariin verrattuna. Kokeita tultaneen jatkamaan vaihtohappamuuden vaikutusten selvittämiseksi tulevina vuosina niin kentällä kuin kasvihuoneessakin. 


\section{Kirjallisuus}

Forsman, K., Virtanen, E. \& Pulkkinen, J. 2003. Happaman lannoitteen vaikutus perunarupeen. Teoksessa: Lannoitus- ja kasvinsuojelukokeiden tuloksia 2002. MTT/ATU ja Kemira. s. 84-89

Hartikainen, H. 1992. Maaperä. Teoksessa: Maa, viljely ja ympäristö. WSOY. s. 8-89

Keinath, A.P. \& Loria, R. 1989. Management of common scab of potato with plant nutrients. In: Engelherd, A.W. (ed.). Soilborne plant pathogens: Management of diseases with micro- and macroelements. The American Phytopathological Society. p. 152-166

Lehtonen, M., Hiltunen, L., Isolahti, M., Koski, P., Laakso, I., Lauronen, M., Palohuhta, J.P., Rantala, H., Reinikainen, O., Vihlman, K., Virtanen, E., Weckman, A. Ylhäinen, A. \& Valkonen, J. 2003. Perunaruven aiheuttajat ja niiden torjunta. Kasvipatologian hankeloppuraportteja no 2, Helsingin yliopisto, Soveltavan biologian laitos. $45 \mathrm{~s}$.

Mizuno, N. \& Yoshida, H. 1993. Effect of exchangeable aluminium on the reduction of potato scab. Plant and Soil 155/156: 506-508

Mäntylahti, V. 2005. Vaihtohappamuuden vaikutusta tutkitaan. Leipä leveämmäksi 53: (5), 38-39

Pietilä, L. 1993. Perunarupi. Teoksessa: Perunan kasvinsuojelu. Tieto tuottamaan 66: 46-49

Saigusa, M., Shoji, S. \& Takahashi, T. 1980. Plant root growth in acid Andosols from northeast Japan. 2. Exchange acidity Y1 as a realistic measure of aluminium toxicity potential. Soil Science 130: 242-250

Shiga, H. \& Suzuki, K. 2004. Effect of soil acidity, organic soil amendment and green manure on potato scab. In: Novel approaches to the control of potato scab. Abstracts of the International Potato Scab Symposium, september 6.-7., Sapporo, Japan. p. 233-237

Tanaka, T. 2004. Integrated control of potato scab according to incidence level. In: Novel approaches to the control of potato scab. Abstracts of the International Potato Scab Symposium, september 6.-7., Sapporo, Japan. p. 243-258

Valkonen, J., Kreuze, J., Kortemaa, H. \& Rantala, H. 1999. Ennestään tuntemattomat sädebakteerit perunaruven aiheuttajina. Kasvinsuojelulehti 32:59-62 